\title{
Morphological and Flow Cytofluorometrical Analyses of Regenerated Rat Thymus after Irradiation
}

\author{
Yoshihisa FuJIKura ${ }^{1}$, Yu-Hsueh WANG ${ }^{1}$, Masahiro Tsuchida ${ }^{2}$, Yukio OHBa ${ }^{3}$, Motohiko Konishi ${ }^{2}$, \\ Masafumi YamaUCHI ${ }^{2}$, Hidefumi KaWAMURA ${ }^{2}$, Tomoo SAWAdA ${ }^{1}$, Nobuko ToKUdA ${ }^{1}$, Min-Kyu ChoI $^{1}{ }^{*}$, \\ Katsusuke NAITo ${ }^{2}$ and Tetsuo Fukumoto ${ }^{1}$
}

Departments of Anatomy ${ }^{1}$, Urology ${ }^{2}$, and Neurology ${ }^{3}$, Yamaguchi University School of Medicine, Ube, Japan

Received February 21, 1997

\begin{abstract}
Summary. Reconstituted rat thymuses were studied by immunohistochemistry, transmission electron microscopy (TEM) and flow cytofluorometry on days $0,1,2,3$, 5 , and 7 after whole-body sublethal irradiation (6 Gy). One day after irradiation, numerous apoptotic cells were seen in the cortical thymus; the percentage of the sub-G1 peak representing apoptotic cells was $8.9 \%$ in the DNA content histogram of cytofluorometry. On day 3 , the thymic structure had been destroyed and no distinction was drawn between the cortex and medulla. In this stage, few thymocytes but many macrophages were present, and the percentage of the sub-G1 peak reached a peak at $\mathbf{1 3 . 0 \%}$. Bromodeoxyuridine (BrdU) incorporated cells gradually increased after irradiation, and immunohistochemically numerous apoptotic cells were found primarily in the cortex on day 7. These thymocytes showed some levels of electron density of the nucleus as revealed by TEM. The percentage of $S$ phase cells did not change markedly $(20-30 \%)$ based on one-color DNA content histograms, but the percentage of early $S$ and $S$ phase cells was extremely high on day $7(70 \%)$. These data indicate that a part of DNA synthetic cells may result in apoptosis. The combination of immunohistochemistry, TEM and flow cytofluorometry to analyze DNA content and BrdU incorporation proved a useful tool for investigating the reconstituted thymus.
\end{abstract}

Ontogenical studies have shown that $\mathrm{T}$ precursor cells develop from hematopoietic stem cells, and enter the subcapsular region of the thymus via blood vessels during the embryonic period (see review by $\mathrm{BACH}$, 1982). These cells then mature in the thymus to become $\mathrm{T}$ cells and migrate to the periphery. The steps of the $T$ cell differentiation have been examined primarily by cell surface markers such as CD3, CD4, $\mathrm{CD} 8, \mathrm{TCR} \alpha \beta$, and MHC class I antigens. T precursor cells are believed to differentiate into $\mathrm{CD} 4^{-} \mathrm{CD} 8^{-}$ (double negative) $\mathrm{T}$ cells, and then $\mathrm{CD} 4^{+} \mathrm{CD} 8^{+}$(double positive) $\mathrm{T}$ cells in the thymic cortex. The double positive $\mathrm{T}$ cells may further develop into $\mathrm{CD} 4^{+} \mathrm{CD} 8^{-}$ or $\mathrm{CD}^{-}{ }^{-} \mathrm{CD} 8^{+}$(single positive) cells in the medulla as mature $\mathrm{T}$ cells to prepare for migration to the periphery.

Thymic destruction occurs after irradiation (TSUCHIDA et al., 1994a; KONISHI et al., 1994; FREDRICKSON and BASCH, 1994), or with the administration of some immunosuppressants such as FK506 (TAKAI et al., 1991, 1992; TsuCHIDA et al., 1994b), and glucocorticoid (TsuchidA et al., 1994b, c). Previous authors have examined the reconstituted thymus using monoclonal antibodies against the surface markers of the thymocytes and shown the existence of subpopulations of the cells not found in normal rats and mice. For example, TSUCHIDA et al. (1994a, c) demonstrated the appearance of immature single positive cells or double negative TCR ${ }^{\text {high }}$ cells after irradiation, FREDRICKSON and BASCH (1994) found double negative $\mathrm{CD} 3^{\text {high }}$ or Thy $1^{-} \mathrm{CD} 4$ single positive TCR $\alpha \beta^{-1 \text { low }}$ cells. KLASSEN et al. (1993), on the other hand, examined radiation-induced apoptosis of rat thymocytes using transmission electron microscopy (TEM). They reported an enlargement of the nuclear and cytoplasmic volumes. Drastic rescue effort certainly occurs in the reconstituting thymus to supply mature $\mathrm{T}$ cells to the periphery, and many thymocytes divide and proliferate. However, there have been few reports that examined cell proliferative activity in these reconstituting thymuses.

*Permanent address: Department of Anatomy, Won Kwang University Medical School, Iksan, Chollabuk-Do, 570-749, Republic of Korea. 
The purpose of this study was to examine the relationship between apoptosis and DNA synthesis from the viewpoint of cell kinetics using immunohistochemical, and flow cytofluorometrical analysis as well as TEM in the sublethal irradiated rat thymus.

\section{MATERIALS AND METHODS}

\section{Animals}

Specific pathogen-free DA strain rats, 7 to 8 weeks old, were used. All animals were housed in an environment with controlled temperature and humidity on a 12-h alternating light/dark cycle with free access to food and water.

\section{Irradiation and experimental protocol}

The rats received whole-body irradiation (6 Gy) on day 0. An X-ray irradiator (Hitachi; MBR-1520R, Tokyo, Japan) was operated at the rate of $1 \mathrm{~Gy} / \mathrm{min}$ with $0.5 \mathrm{~mm} \mathrm{Al}$ and $0.1 \mathrm{~mm} \mathrm{Cu}$ filters. Bromodeoxyuridine (BrdU) solution was administered at a dose of $50 \mathrm{mg} / \mathrm{kg}$ body weight (DolBEARE et al., 1983) in rats on days $0,1,2,3,5$, and 7 after irradiation. One hour following this, they were killed by inhaling an overdose of diethyl ether.

\section{Immunohistological analysis}

The thymus from each rat was removed, fixed by immersion in $3 \%$ formaldehyde solution and embedded in paraffin. Localization of BrdU uptake was examined according to an indirect immunoperoxidase staining method. Briefly, thin sections were reacted with anti-BrdU antibody (Becton Dickinson, San Jose, CA, USA) for $1 \mathrm{~h}$ at room temperature after deparaffinization and $0.03 \% \mathrm{H}_{2} \mathrm{O}_{2}$ treatment. They were washed three times in phosphate buffered saline (PBS) and incubated with horseradish peroxidase (HRP) conjugated goat $\mathrm{F}\left(\mathrm{ab}^{\prime}\right) 2$ anti-mouse IgG (DAKO, Carpinteria, CA, USA) at appropriate concentrations with $5 \%$ of heat-inactivated normal rat serum for $1 \mathrm{~h}$ at $4^{\circ} \mathrm{C}$. After being rinsed in PBS, sections were developed with $3,3^{\prime}$-diaminobenzidine-tetrahydrochloride (DAB) containing $0.03 \% \quad \mathrm{H}_{2} \mathrm{O}_{2}$, and lightly counterstained with hematoxylin.

Apoptotic cells were visualized in $6-\mu \mathrm{m}$ thick sections from the rat thymuses using the terminal deoxynucleotidyl transferase (TdT) mediated dUTP-biotin nick end labeling (TUNEL) reaction by ApopTag kit (Oncor, Gaithersburg, MD, USA) with minor modifications. Briefly, protein in the sections was digested with proteinase K (Sigma, St. Louis, MO, USA), and rinsed with PBS. The sections were post-fixed with ethanol/ acetic acid $(2: 1)$ for $5 \mathrm{~min}$ at $-20^{\circ} \mathrm{C}$, treated with $\mathrm{H}_{2} \mathrm{O}_{2}$, and washed. They were reacted with the mixture of $\mathrm{TdT}$ and reaction buffer at $37^{\circ} \mathrm{C}$ in a humid chamber, then developed with Vectastain-ABC kit and $\mathrm{DAB}$ solution. The sections were lightly counterstained with hematoxylin.

A part of the thymuses were quickly frozen in OCT compound. Thin frozen sections were stained with ED1, ED2 (DIJKsTRA et al., 1985) and HAM8 (FUJIKURA et al., 1993) monoclonal antibodies using indirect immunoperoxidase staining. In brief, the sections were fixed in acetone/methanol $(1: 1)$ at $-20^{\circ} \mathrm{C}$ for 10 min. After rinsing with PBS, they were treated with these monoclonal antibodies followed by HRP-conjugated anti-mouse $\mathrm{IgG}$, visualized with $\mathrm{DAB}$, and counter stained. HAM8 was used as a control monoclonal antibody which recognizes connexin 32 of gap junction and belongs to the same mouse immunoglobulin class of ED1 or ED2.

For TEM study, tissues from normal thymuses and from the organ 3 and 7 days after irradiation were fixed with $2 \%$ glutaraldehyde in a $0.1 \mathrm{M}$ phosphate buffer ( $\mathrm{pH}$ 7.4) for $10 \mathrm{~min}$. They were postfixed with $2 \%$ osmium tetroxide in the same buffer for $2 \mathrm{~h}$ at room temperature, dehydrated with a graded acetone series, and embedded in Epon 812. About $190 \mathrm{~nm}$ thick ultrathin sections were stained with $2 \%$ uranyl acetate for $10 \mathrm{~min}$ followed by lead citrate for $5 \mathrm{~min}$. They were observed with a $200 \mathrm{CX}$ TEM (JEOL, Tokyo, Japan) at $160 \mathrm{kV}$.

\section{Flow cytometrical analysis}

Thymocyte suspensions prepared from the irradiated rats were stained with anti-BrdU antibody and propidium iodide (PI) (Calbiochem, San Diego, CA, USA) solution. Briefly, the cells were suspended in $1 \mathrm{ml}$ of PBS, fixed with $5 \mathrm{ml}$ of $-20^{\circ} \mathrm{C}$ ethanol, stored overnight at $4^{\circ} \mathrm{C}$, washed with PBS, and left for 30 min at room temperature in $4 \mathrm{~N} \mathrm{HCl}$. The thymocytes were then reacted with anti-BrdU antibody solution containing $0.5 \%$ Tween $20,0.5 \%$ bovine serum albumin, and $10 \%$ normal goat serum. They were again washed with PBS and reacted with fluorescein isothiocyanate (FITC)-conjugated anti-mouse IgG. Finally, the suspended cells were treated with $0.1 \%$ RNase (Sigma, St. Louis, MO, USA), and reacted with $0.1 \%$ PI in PBS. These samples were analyzed with FACScan equipment (Becton Dickinson, San Jose, CA, USA) using CellFit software. To measure the DNA content with PI, the samples were gated to a single cell area. To clarify the relation between DNA content (PI fluorescence) and BrdU incorporation (FITC fluorescence) for each cell, twocolor analysis was carried out. 

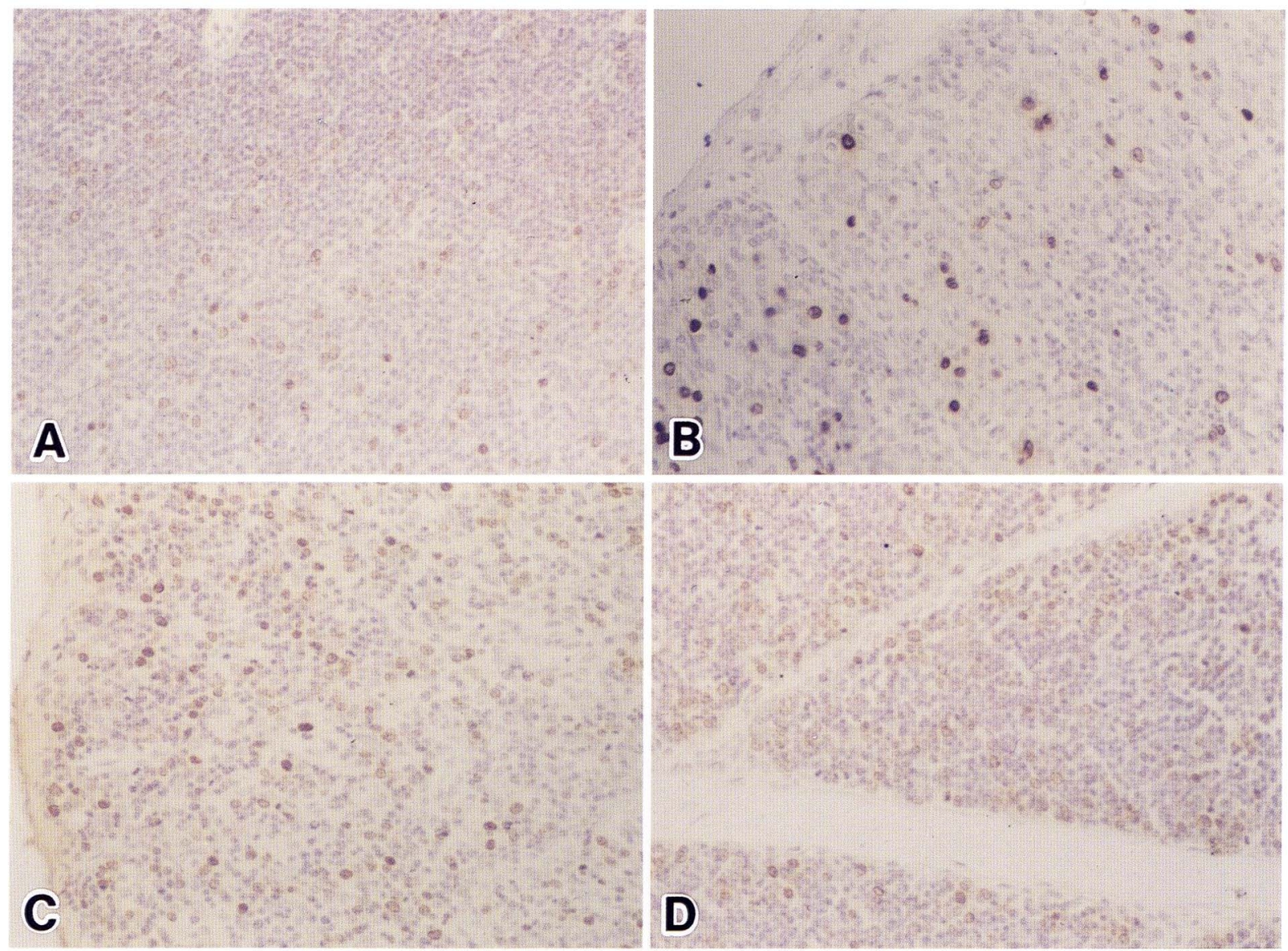

Fig. 1. Immunohistochemical staining of thymus tissues from irradiated rats using anti-bromodeoxyuridine (BrdU) antibody. Counterstain with hematoxylin. BrdU incorporated cells (brownish) are seen primarily in the medullary thymus from a normal rat (A). Signals strongly positive for BrdU can be recognized in the tissue at day $3(\mathbf{B})$. On days $5(\mathbf{C})$ and $7(\mathbf{D})$, many BrdU incorporated cells appear mainly in the cortex. $\times 100$

\section{RESULTS}

\section{Immunohistochemical analysis}

BrdU incorporated cells were diffusely scattered in the medulla of the normal rat thymus (Fig. 1A). On day 3 after irradiation, the normal thymic structure was destroyed and could not be distinguished from the cortex and medulla. At this stage, strongly BrdUpositive cells appeared distributed throughout the thymic tissue (Fig. 1B). On days 5 and 7 after treatment, BrdU-positive cells increased in number in the cortex and medulla and located primarily in the subcapsular region of the cortex (Fig. 1C, D), though the thymic structure began to normalize during this period. Thus, the BrdU-positive cell ratio gradually increased during this time period.

TUNEL-positive cells were few in number in the normal rat thymus (Fig. 2A). On 1 day after irradia- tion the deteriorated thymus barely maintained the cortex and medullary structure, and many cells in the cortex became strongly TUNEL-positive (Fig. 2B). Three days after treatment, apoptotic cells were evenly distributed in the severely destroyed and/or reconstituted thymus (Fig. 2C). Numerous apoptotic cells were still present in the tissues from 5 or 7 days after irradiation, though the positive cell ratio was lower than that of day 3 (Fig. 2D).

A few ED1 positive cells were scattered in the cortex and medulla of the normal rat thymus. Positive cell frequency in the medulla was higher than that in the cortex (Fig. 3A). One day after irradiation, many strongly ED1 positive cells were seen evenly in the cortex and medulla of the thymus (Fig. 3B). In destroyed thymus tissue from 3 days after irradiation, ED1 positive cells were seen throughout the thymus, though the number was small compared to the findings on day 1 (Fig. 3C). Five days after irradia- 

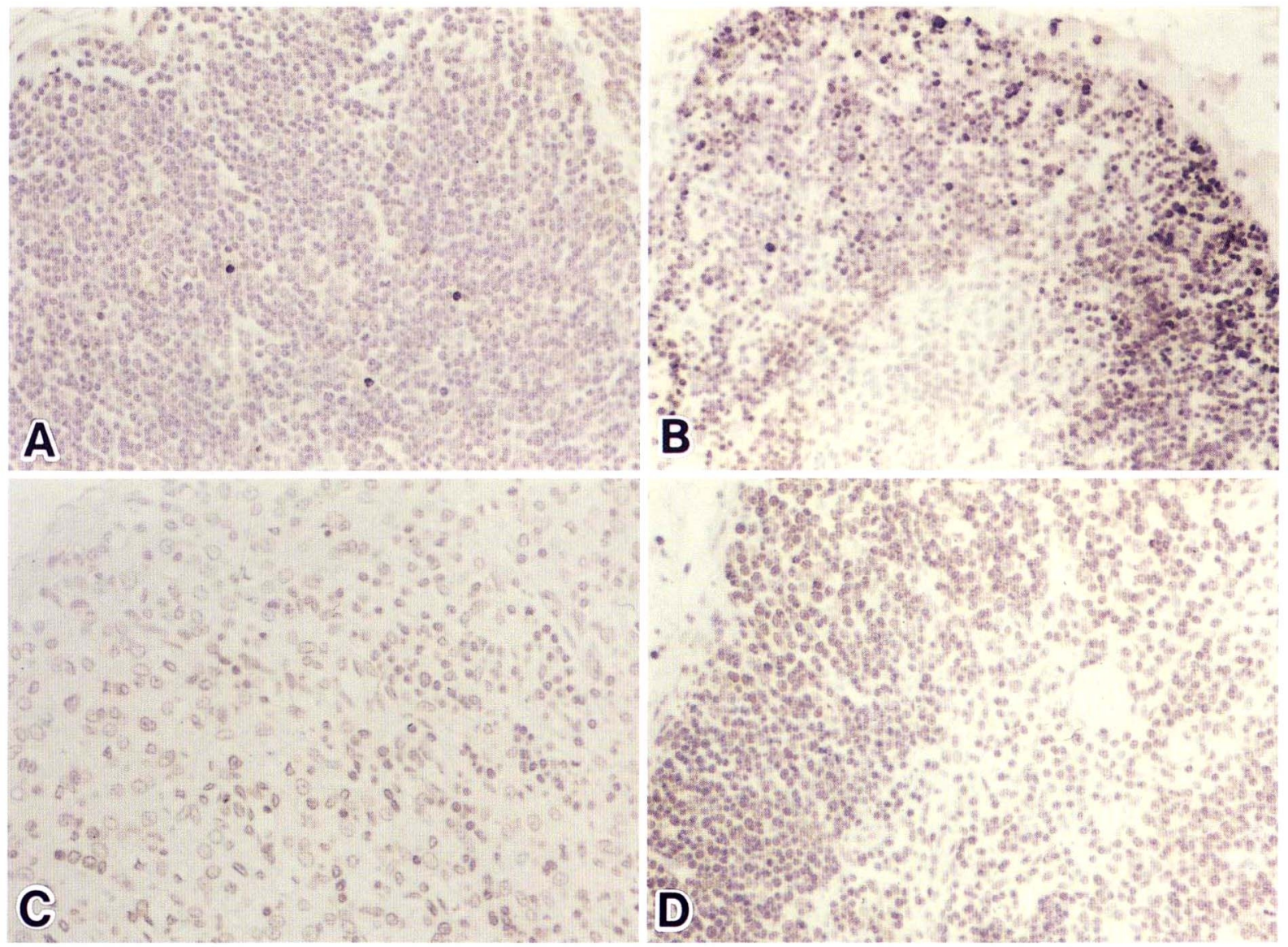

Fig. 2. Immunohistochemical staining of thymic tissues from irradiated rats using Apop Tag kit. Counterstain with hematoxylin. Marked apoptosis (brownish) is found in the thymic cortex 1 day after irradiation (B) compared with normal thymus tissue (A). On day $3(\mathbf{C})$, apoptotic cells are evenly distributed in the destroyed and/or reconstituted thymus. Many apoptotic cells are still present on the tissues 5 days after irradiation (D). $\times 100$

tion, ED1 positive cells were mainly recognized in the thymic cortex (Fig. 3D). The findings of ED1 positive cell distribution on day 7 was similar to that of day 1 (data not shown).

ED2 positive cells were very small in number; they were distributed diffusely in normal rat thymus, being mainly located in the cortex. One day after irradiation, ED2 positive cells increased in number mainly in the cortex. However, no ED2 positive cells were seen in the thymus parenchyma on days 3,5 and 7 after irradiation (data not shown).

\section{Ultrastructure of normal and irradiated rat thymus}

Many thymocytes were seen in the normal rat thymus (Fig. 4A). Three days after irradiation, the number of thymocytes became small, while macrophages phagocytosing many destructive thymocytes increased in number markedly. Some collagen fibers were noticeable between macrophages (Fig. 4B). On day 7 , the relative number of thymocytes increased. The thymocytes had a nucleus of a varying size and shape (Fig. 4C).

\section{Flow cytofluorometrical analysis}

In normal rats (Fig. 5, day 0), many thymocytes were in $\mathrm{G} 0 / \mathrm{G} 1$ phase of the cell cycle showing the G0/G1 peak which was revealed by low DNA content in the one color flow cytofluorometrical histogram. One day after irradiation, the sub-G1 peak which had less DNA was seen on the one color histogram at the left side of the G0/G1 peak and occupied $8.9 \%$ of total cell number (Fig. 5, day 1, Table 1). The peak reached its maximum level on day $3(13.0 \%)$ and then decreased during the ensuing days. $\mathrm{S}$ phase cells were recognized in the one color histogram between G0/G1 phase cells and G2/M phase cells which had 2 times 

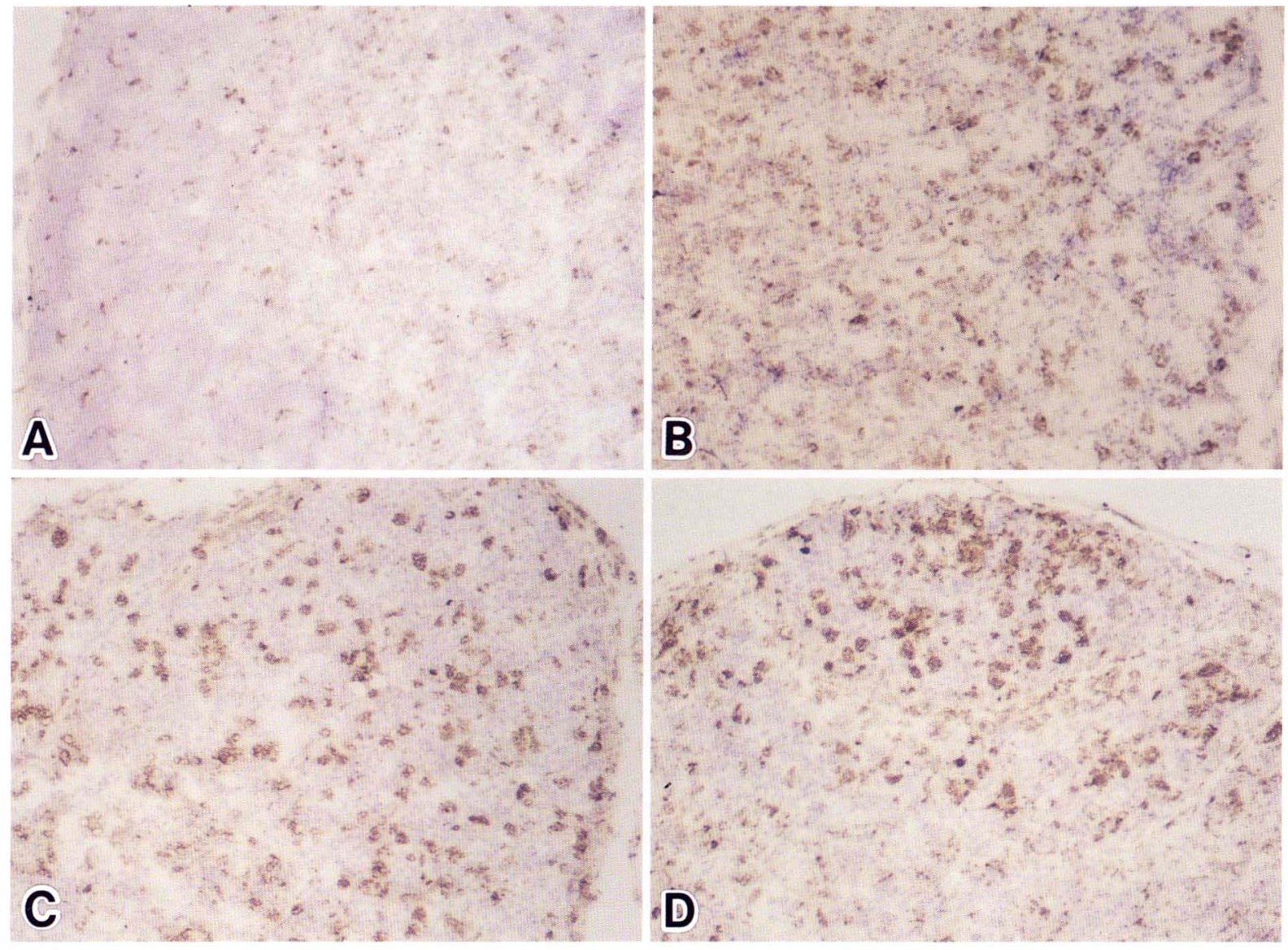

Fig. 3. Immunohistochemical staining of thymic tissues from irradiated rats using ED1 monoclonal antibody. Counterstain with hematoxylin. A few ED1 positive macrophages (brownish) are recognized diffusely in normal rat thymus (A). Many positive cells are seen in the thymus 1 day after irradiation (B). ED1 positive macrophages are evenly recognized in the destroyed thymus from 3 days after irradiation (C). Five days after irradiation (D), ED1 positive cells are seen mainly in the cortex. $\times 50$

volume of DNA in the cell nucleus and located 2 times fluorescence channels in FL2-A. The percentage of S phase cells on day 7 was approximately $30 \%$, which was 1.5 times greater compared with that from normal rat thymocytes (Table 1). Figure 6 shows the histograms from the two-color analysis. Cell groups with a few DNA seen on days $1,2,3$, and 5 did not uptake BrdU in vivo showing the existence of apoptotic cells. The cells in Figure 6 which had low content of DNA were equivalent to the cells of the sub-G1 peak appeared in Figure 5. On day 7 after irradiation, there were two groups of G0/G1 phase cells. A newly recognized cell group located on top of the G0/G1 cell group, which was referred to as the early S phase cells, and they uptook much BrdU (Fig. 6 , day 7 , square). The percentages of the early $\mathrm{S}$ phase cells plus S phase cells amounted to 70\% (data not shown).

\section{DISCUSSION}

The present study has clearly demonstrated that thymocytes show marked DNA synthesis and apoptosis during the reconstitution of the rat thymus after 6 Gy whole-body irradiation. In the normal rat thymus in this study, there were few BrdU incorporated cells and apoptotic cells, as seen by immunohistochemical staining and flow cytofluorometrical analysis using anti-BrdU antibody and the TUNEL method. A previous report showed that most of thymocytes fell into apoptosis during negative selection (KAPPLER et al., 1987) as analyzed by cell surface antigens such as TCR, CD4, CD8 and MHC class II using flow cytofluorometry. However, the present study has revealed that apoptotic cells in normal rat thymus tissue comprised less than $2 \%$ in flow cyto- 

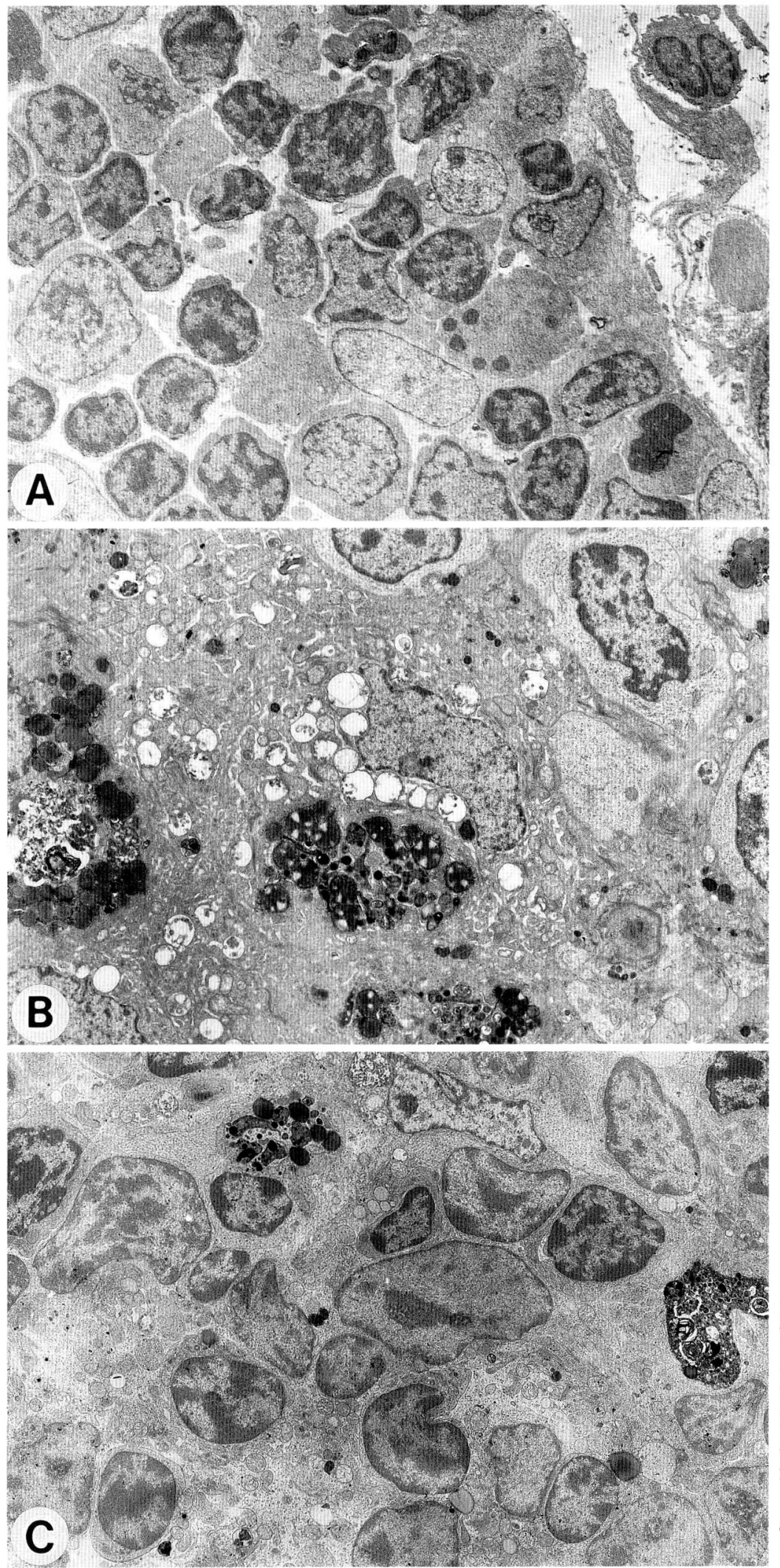

Fig. 4. Irradiated rat thymuses examined by transmission electron microscopy (see text) A. Many thymocytes were seen in nomal rat thymus. $\times 3,000$. B. Three days after irradiation, macrophages phagocytosed destroyed thymocytes in the cytoplasm, and fibers are noticeable in the interstitium. $\times 3,600$. C. Thymocytes express various electron densities, sizes and nuclear shapes 7 days after irradiation. $\times 3,000$ 

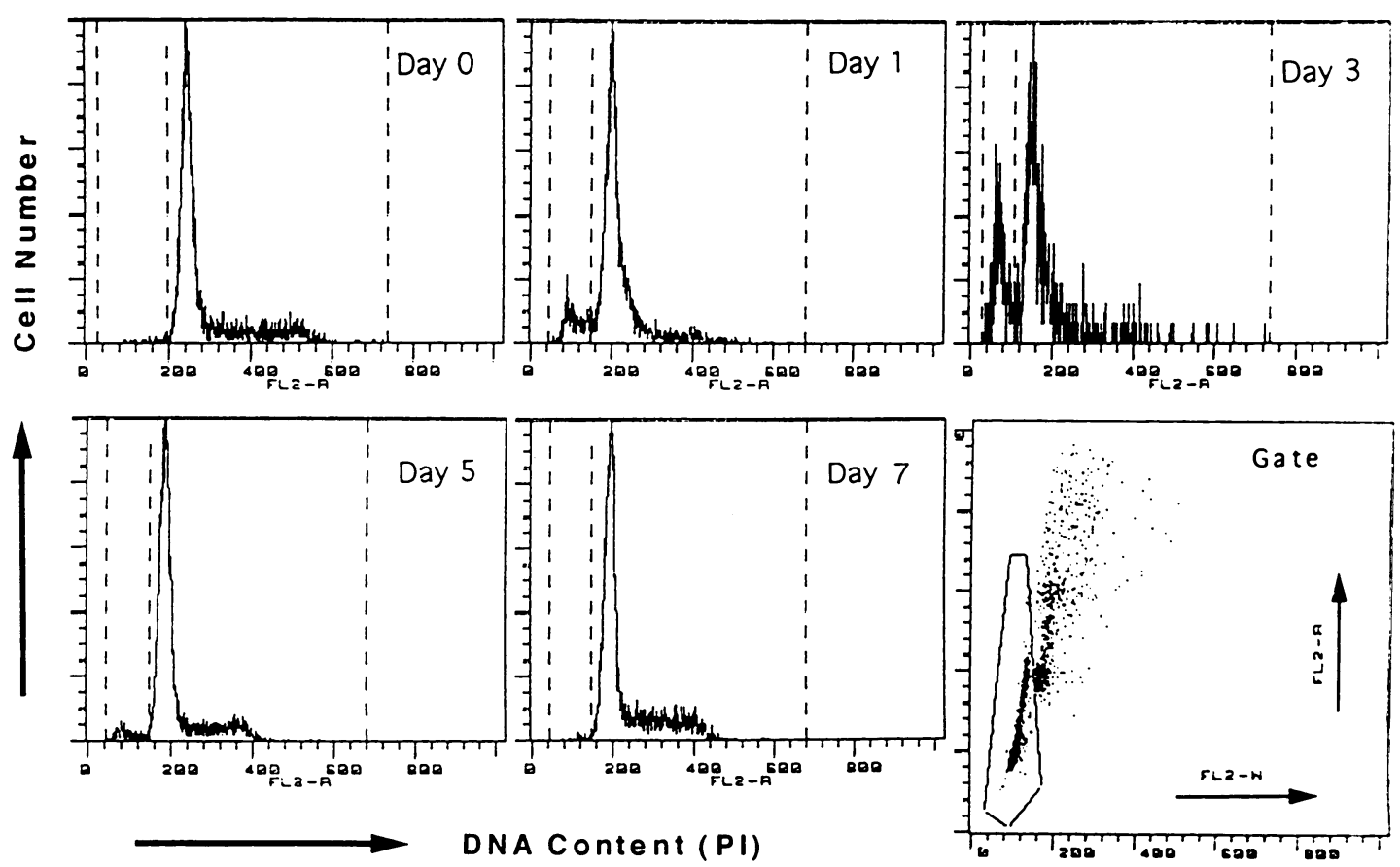

Fig. 5. Flow cytofluorometrical analysis of DNA content from irradiated rat thymuses. DNA stained with propidium iodide (PI). The vertical scales are not comparable because they have been modified to allow visualization of small populations. Gaited thymocytes were analyzed as shown in the lower right square. Thymocytes have a sub-G1 peak-like pattern and decreased G2/M ratio on day 3 after irradiation. Many cells belonging to the S phase are seen on day 7. FL2-W: horizontal scale indicates fluorescence width; FL2-A: vertical scale indicates fluorescence area. Both have been calculated electrically.

Table 1. The percentages of each phase cells after irradiation

\begin{tabular}{|c|c|c|c|c|c|}
\hline \multirow{2}{*}{$\begin{array}{l}\text { Days after } \\
\text { irradiation }\end{array}$} & \multirow{2}{*}{$\mathrm{n}$} & sub-G1 & G0/G1 & $\mathrm{S}$ & $\mathrm{G} 2 / \mathrm{M}$ \\
\hline & & \multicolumn{4}{|c|}{ mean $\pm \mathrm{SD}(\%)$} \\
\hline 0 & 8 & $1.9 \pm 1.4$ & $74.1 \pm 8.2$ & $21.0 \pm 7.0$ & $4.9 \pm 2.6$ \\
\hline 1 & 2 & $8.9 \pm 4.5$ & $63.7 \pm 6.1$ & $28.8 \pm 10.3$ & $7.5 \pm 6.4$ \\
\hline 3 & 4 & $13.0 \pm 6.1$ & $77.1 \pm 13.8$ & $19.5 \pm 15.3$ & $3.4 \pm 2.6$ \\
\hline 5 & 5 & $7.4 \pm 5.2$ & $70.5 \pm 5.2$ & $21.5 \pm 3.8$ & $8.0 \pm 3.4$ \\
\hline 7 & 5 & $1.2 \pm 1.4$ & $63.1 \pm 11.0$ & $30.2 \pm 8.5$ & $6.6 \pm 5.3$ \\
\hline
\end{tabular}

Thymocytes from each irradiated rat were stained with PI solution to reveal the DNA content. The samples were analyzed by one color flow cytofluorometrical analysis and the percentage of each phase was calculated electrically. $\mathrm{n}=$ animal number. 


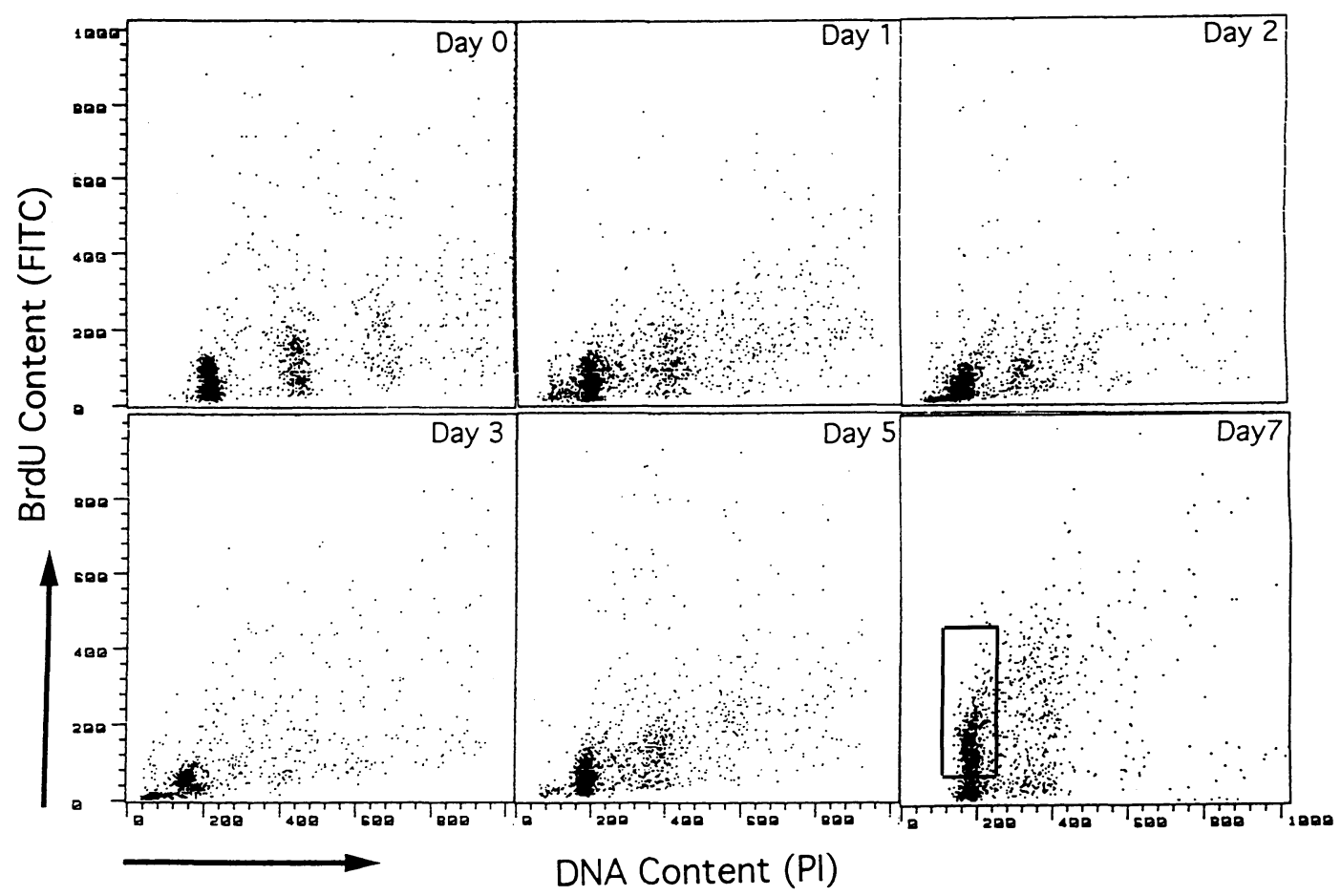

Fig. 6. Two-color flow cytofluorometrical analysis of BrdU uptake and DNA contents from irradiated rat thymuses. The suspended thymocytes were stained with anti-bromodeoxyuridine (BrdU) antibody and propidium iodide (PI). Cell groups with lower DNA content were seen on days 1, 2, 3, and 5, located at the bottom of the BrdU content. Many early S-phase thymocytes were recognized on the top of the G0/G1 cell groups, and had high BrdU signals (square).

fluorometrical histograms (Table 1): the sub-G1 peak's appearance in one color DNA histograms means the existence of apoptotic cells, because short fragmented DNA in the nucleus of apoptotic cells had disappeared from the cells and the result remained as long fragmented DNA in the nucleus (DARZYNKIEWICZ et al., 1992; GoNG et al., 1994; MurAKAMI et al., 1995). The discrepancy may be explained by previous reports that apoptotic cells are rapidly phagocytozed by macrophages or neighboring stroma cells such as epithelial cells (RAFF, 1992; TAN, 1994).

ED1 and ED2 monoclonal antibodies were first reported by DIJKSTRA et al. (1985) for markers of rat macrophage subsets. MATSUNO et al. (1996) reported recently that the ED1 antigen might be rat CD68, whereas ED2 antigen might be of an integrin family. Our findings suggested that many thymic cells were damaged by 6 Gy whole body irradiation within 1 day, and many thymocytes resulted in apoptosis. It is interesting that many ED1 positive macrophages in this stage appeared and phagocytosed these apoptotic thymocytes mainly in the cortex. This finding may be explained in that cortical thymocytes are more radiosensitive than medullary cells and rapidly phagocytosed by cortical macrophages. However, a short time course analysis is necessary to examine in detail degeneration analysis.

On days 5 and 7 , thymocytes increased in number dramatically (TsuchIDA et al., 1994b). Our findings have shown that DNA synthesis was activated in cortical thymocytes and early S phase cells appeared in two color histograms. Early S phase cells may be present in the reconstituted thymic cortex and have a proliferative activity. Indeed, we showed that there were some kinds of thymocytes such as large or small cells, electron dense or light cells, or polygonal thymocytes from the TEM findings. These thymocytes may synthesize DNA actively but the DNA may be soon fragmented as detected by the TUNEL method. They may belong to the early $\mathrm{S}$ phase in Figure 6, day 7, and phagocytosed by ED1 positive macrophages. From these results, we speculate that many BrdU incorporated cells may result in apoptosis, though macrophages could not multiply to phagocytose the apoptotic cells. Furthermore, we found large foamy macrophages in the thymus tissue from 
rats 7 days after irradiation with 7 continuous treatments of deoxyspergualin (immunosuppressant) (KAWAMURA et al., unpublished data). TAKAI et al. (1991, 1992) reported the increased macrophage-like phagocytic activity as a patchy reduction in FK-506 treated rat thymus. Thus, we consider that macrophages phagocytosed actively the degenerated thymocytes in immunosuppressive conditions in vivo. It will be necessary to use both immunohistochemical staining and flow cytofluorometrical analysis to examine further the reconstituted thymus.

Acknowledgements. We thank Prof. K. SASAKI, Dr. T. Murakami, Mrs. Y. Mimura (Department of 2nd Pathology, Yamaguchi University School of Medicine) and Dr. K. IKeмото (Department of Neurology, Yamaguchi University School of Medicine) for their advices and technical operation of FACScan equipment

\section{REFERENCES}

BACH, J. F.: B and T lymphocytes. In: (ed. by) J. F. BACH: Immunology, 2nd ed. John Wiley and Sons Inc., New York, 1982 (p. 60-105).

Darzynkiewicz, Z., S. Bruno, G. Delbino, W. Gorczyca, M. A. Hotz, P. Lassota and F. Traganos: Feature of apoptotic cells measured by flow cytometry. Cytometry 13: 795-808 (1992).

Dijkstra, C. D., E. A. DopP, P. Joling and G. KraAlR: The heterogeneity of mononuclear phagocytes in lymphoid organs: Distinct macrophage subpopulations in the rat recognized by monoclonal antibodies ED1, ED2 and ED3. Immunology 54: 589-599 (1985).

Dolbeare, F., H. Gratzner, M. G. Pallavicini and J. W. GRAY: Flow cytometric measurement of total DNA content and incorporated bromodeoxyuridine. Proc. Nat. Acad. Sci. USA 80: 5573-5577 (1983).

Fredrickson, G. G. and R. S. BASCH: Early thymic regeneration after irradiation. Devel. Comp. Immunol. 18: 251-263 (1994).

Fujikura, Y., H. Ohta, T. Hirai and T. Fukumoto: Immunohistochemical analysis of rat liver using a monoclonal antibody (HAM8) against gap junction. Anat. Rec. 235: 335-341 (1993).

Gong, J., F. Traganos and Z. Darzynkiewicz: A selective procedure for DNA extraction from apoptotic cells applicable for gel electrophoresis and flow cytometry. Anal. Biochem. 218: 314-319 (1994).

Kappler, J. W., N. Roehm and P. Marrack: T cell tolerance by clonal elimination in the thymus. Cell 49: 273-280 (1987).

Klassen, N. V., P. R. W Alker, C. K. Ross, J. Cygler and B. LACH: Two-stage cell shrinkage and the OER for radiation-induced apoptosis of rat thymocytes. Int. J. Radiat. Biol. 64: 571-581 (1993).
Konishi, M., K. Takai, K. JoJima, Y. Fujikura, K. NaIto and T. FUkU мото: Effects of FK506 on surface antigen expression by regenerating thymocytes after sublethal irradiation in the rat. Thymus 23: 53-66 (1994).

Matsuno, K., T. Ezaki, S. Kudo and Y. Uehara: A life stage of particle-laden rat dendritic cells in vivo: Their terminal division, active phagocytosis, and translocation from the liver to the draining lymph. J. Exp. Med. 183: 1865-1878 (1996).

Murakami, T., X. Li, J. Gong, U. Bhatia, F. Traganos and Z. DARZYNkiewicz: Induction of apoptosis by 5azacytidine: Drug concentration-dependent differences in cell cycle specificity. Cancer Res. 55: 3093-3098 (1995).

RAFF, M. C.: Social control on cell survival and cell death. Nature 356: 397-400 (1992).

Takai, K., M. Tsuchida, M. Konishi, N. ToKuda, Y. Fujikura, K. Jojima and T. Fukumoto: Immunosuppressive effects of FK506 on rat lymphoid organs. Transplant. Proc. 23: 2964-2966 (1991).

Takai, K., N. Tokuda, T. Sawada, Y. FujIKura, K. Jojima, J. Sakatoku and T. Fukumoto: Effects of FK506 on rat thymic epithelial cells; immunohistochemical study. Thymus 19: 207-217 (1992).

TAN E. M.: Autoimmunity and apoptosis. J. Exp. Med. 179: 1083-1086 (1994).

Tsuchida, M., M. Konishi, K. TakaI, K. Naito, Y. Fujikura and T. Fukumoto: Effects of irradiation, glucocorticoid, and FK506 on cell surface antigen expression by rat thymocytes: a three-color flow cytofluorometric analysis. Immunology 83: 469-475 (1994a).

Tsuchida, M., K. TAKaI, K. JoJima, K. NaITo, Y. FUJIKURA and T. Fukumoto: The effects of FK506 and dexamethasone on rat thymocyte differentiation. Therap. Immunol. 1: 135-141 (1994b).

Tsuchida, M., M. Konishi, K. JoJima, K. Naito, Y. Fujikura and T. Fukumoto: Analysis of cell surface antigen on glucocorticoid-treated rat thymocytes with monoclonal antibodies. Immunol. Lett. 39: 209-217 (1994c).

Dr. Yoshihisa FuJIKuRA Department of First Anatomy Yamaguchi University School of Medicine 1144 Kogushi, Ube 755 Japan

藤 倉 義 久 755 宇部市西区小串 1144 山口大学医学部 第一解剖学教室 